Paper published in the Journal Ageing International, 2017

The publication is available at: https://link.springer.com/article/10.1007/s12126-017-9298-2

Open Access (read-only): http://rdcu.be/ub6J

Cruz-Martínez, Gibrán (2017). Revenue-Generating Potential of Taxation for Older-Age Social Pensions. Ageing International. DOI: 10.1007/s12126-017-9298-2

\title{
Revenue-Generating Potential of Taxation for Older-Age Social Pensions ${ }^{1}$
}

\author{
Gibran Cruz-Martinez \\ gibrancm@uia.no
}

\begin{abstract}
Social security and taxation operate jointly to overcome individual deprivations, reduce income inequality and promote development, bringing 'taxation into social protection analysis and planning'. There are several ways in which governments can create fiscal space to finance social protection programmes (e.g. social pensions). The idea is to create new sources of revenue -sustainable in the long-run - which can be used to finance social pensions, without building new liabilities and without distorting macroeconomic stability. The literature specifically addressing the potential fiscal space that could be created to finance social pensions is limited. This paper aims to begin filling some of those gaps and identify sources for creating fiscal space for social pensions through the revenue side (i.e. examine the revenue-generating potential of taxation for social pensions). Specifically, examine the potential funding power of three types of taxes (income tax, corporate tax, and trade tax) using cross-country tax revenues and tax rate data in a global perspective. The paper demonstrates that the three taxes have a revenue-generating potential to finance social pensions in several countries. There is not a magic prescription useful for every country, but there are numerous options to design a tailored mix of sources to create fiscal space.
\end{abstract}

Keywords: social pensions; fiscal space; social protection; tax revenue; taxation; cash transfers; poverty reduction

1 This study was funded by Help Age International, while the author was a Research Fellow. 


\section{INTRODUCTION}

Social security and social assistance programmes are intended to reduce income poverty and equalize (to one degree or another) income distributions via government intervention. In the case of social pensions - also known as non-contributory pensions - basic income security, and intergenerational redistribution are among the primary components of intervention. Income transfers from the government to the most vulnerable segments of the population are one route to reduce income poverty and inequality (the expenditure side of poverty and inequality reduction). In the case of the older age population, transfers received through pensions increase their disposable income allowing them to satisfy social risks and ameliorate individual deprivations associated with income security.

But, what about the revenue side? Current thinking has evolved to conceptualize income security and inequality reduction as a goal resulting from the net effects of income and expenditure interventions. Social security and taxation operate jointly to overcome individual deprivations, reduce income inequality and promote development, ${ }^{2}$ bringing 'taxation into social protection analysis and planning' (Bastagli, 2015). Now the question is, how and from where to increase government revenues in order to fund the expenditure side of poverty and inequality reduction? This is the fiscal space which is often seen as a barrier to resourcing social protective interventions - i.e., the 'room in a government's budget that allows it to provide resources for a desired purpose without jeopardizing the sustainability of its financial position or the stability of the economy' (Heller, 2005). There are several ways in which governments can create fiscal space to finance social protection programmes (e.g. social pensions). The idea is to create new sources of revenue -sustainable in the long-runwhich can be used to finance social pensions, without building new liabilities and without distorting macroeconomic stability.

According to Ortiz, Cummins, and Karunanethy (2015) and Harris (2013), the following are the main sources of fiscal space:

- Domestic tax and non-tax revenues (e.g. Direct taxes, taxes on financial transactions and luxury goods, state-owned enterprises revenues);

\footnotetext{
${ }^{2}$ See Bastagli (2016) for a guidance note and examples of the impact of poverty and inequality on taxes and transfers, and the financing role of taxation in social protection.
} 
- Expenditure redirection or reallocation (e.g. Redirect public spending from non-productive areas such as military expenditure into social protection);

- Expanding social security coverage and contributory revenues (e.g. Increase the amount of workers in the formal sector contributing to welfare programmes);

- Enhancing expenditure efficiency (e.g. Reduce inclusion and exclusion errors);

- Reducing/restructuring/relieving the public debt (e.g. External debt audit to identify illegitimate/odious debt, debt forgiveness);

- External financing and aid transfers (e.g. Loans, grants, high-income countries reaching the 0.7 per cent gni target, redistributing the actual aid among recipients);

- Seignorage (i.e. Revenues derived from printing money);

- Eliminating illicit financial flows (e.g. Money laundering, transfer pricing, tax havens);

- Use of fiscal and central bank foreign exchange reserves;

- Expansionary macroeconomic policy.

Governments can create fiscal space by combining two, three or more of these strategies. There is not a magic prescription useful for every country, but there are numerous options to design a tailored mix of sources to create fiscal space. ${ }^{3}$ Ortiz et al (2015) and Harris (2012) are not alone in proposing sources of fiscal space. An extensive literature base exists on how to create fiscal space to finance social protection (Barrientos \& Niñozarazúa, 2011; Hagen-Zanker \& Tavakoli, 2012; Marcel, 2014; Olivier, 2013). However, the literature specifically addressing the potential fiscal space that could be created to finance social pensions is limited.

This paper aims to begin filling some of those gaps and identify sources for creating fiscal space for social pensions through the revenue side (i.e. examine the revenue-generating potential of taxation for social pensions). The following sections examine the potential funding power of three types of taxes (income tax, corporate tax, and trade tax) using cross-country tax revenues and tax rate data.

\footnotetext{
${ }^{3}$ Durán-Valverde and Pacheco (2012) identified distinct fiscal space creation strategies adopted by eight low- and middle-income countries (Bolivia, Botswana, Brazil, Costa Rica, Lesotho, Namibia, Thailand and South Africa) to finance the extension of social protection. For example, Bolivia's strategies combine natural resources extraction taxes, debt reduction and sales of state assets, while Namibia increased social contributions, used budget surpluses and used official development assistance.
} 


\section{IDENTIFYING AND/OR CREATING FISCAL SPACE VIA TAX REVENUES}

Increasing tax revenues is one option available to governments to create fiscal space. It is useful, first, to analyse the composition of tax revenues by income group and region group before moving our conversation towards proposing options.

The IMF Government Finance Statistics database disaggregate tax revenues in six types of tax: tax on incomes, profit and capital gains, tax on payroll and workforce, tax on property, tax on goods and services, taxes on international trade and transactions and other taxes. Figure 1 shows tax revenues disaggregated by type of tax. Clearly, taxes on income, profits and capital gains (direct taxes), and taxes on goods and services (indirect taxes) are two of the main sources of tax revenues across the seven geographical regions. Europe and Central Asia exhibit the highest average tax revenues (19.1 per cent) followed closely by East Asia and the Pacific (18.1 per cent), and Latin America and the Caribbean (18.1 per cent). OECD members have slightly higher tax revenues (19.9 per cent). The relatively small difference between OECD members, East Asia and Latin America increase significantly if social contributions are taken into account. While social contributions represent 29 per cent of revenues in OECD countries, they represent considerably less inflows for East Asia and the Pacific (5.2 per cent) and Latin America and the Caribbean (11.8 per cent) (CEDLAS \& Bank, 2016).

Now, what if the income level is taken into account to group countries? Four groups are formed using the 2016 World Bank classification: high-, upper-middle-, lower-middle-, and low-income countries. The top two tax revenue sources (direct taxes and indirect taxes) increase on average by 0.7 percentage points while moving up the income classification. On the other hand, tax on international trade and transactions decrease on average by 0.6 percentage points while moving up the income classification. Tax revenues via direct and indirect taxes are positively correlated with income level, while tax revenue via international trade and transactions are negatively correlated with income category.

How much fiscal space could be created by increasing tax revenue to the average/median of OECD countries? According to the most recent data available, 47 countries exhibit a tax revenue level above the OECD average, 
while 106 countries collected tax revenues below that average. ${ }^{4}$ If the OECD median is used as a threshold, 59 countries exhibit a tax revenue level above the threshold and 94 countries below it.

\section{-Figure 1 -}

The histograms in Figure 2 and 3 exhibit the potential fiscal space that could be created if the respective countries increased their tax revenues to OECD levels. Around 27 per cent of countries (29 of 106) would increase up to 3 percentage points of their respective GDP, and up to 31 per cent (33 of 106) would increase from 3 to 6 percentage points. In terms of the OECD median, around 30 per cent of countries (28 of 94) would increase their tax revenues up to 3 percentage points, and up to 40 per cent (38 of 94) would increase their tax revenues an additional 3 to 6 percentage points. Figures 2 and 3 present similar analysis using 9, 12, 15, 18 and 21 percentage point bins. The vast majority of countries are collecting tax revenues below OECD levels; by just looking at the numbers it could be argue that increasing revenues via tax is a factual possibility for many countries. However, in order for this to be a reality countries need to overcome important limitations in tax collection -such as low tax compliance, historical mistrust in the government fiscal capacity (Sánchez Román, 2012), among others.

-Figure 2-

\section{-Figure 3-}

The lower-middle-income group would have the greatest number of beneficiary countries. By increasing tax revenues to OECD levels, 76 per cent of lower-middle-income countries (29 of 38), 71 per cent of low-income countries (15 of 21), 53 per cent of upper-middle-income countries (23 of 43), and 52 per cent of high-income countries (27 of 52), would create substantial fiscal space (See Figure 4). All income groups have a majority of countries that could increase their fiscal space by increasing their tax revenue effort. The question is, how to increase the tax revenue effort? There are two main options available: increasing tax rates and/or reducing tax evasion and elusion.

-Figure 4-

\footnotetext{
${ }^{4}$ The sample comprises 153 cases, of which 51 are labelled as high-income, 43 as upper-middle-income, 38 as lower-middle-income, and 21 as low-income.
} 
An increase in tax rates (the proportion of tax levied on individual's and firm's income, consumption, property, and wealth, etc) implies an increase in the ratio of taxes paid. It is the result of predetermined scales of taxation. Tax evasion, by contrast, is the use of illegal means to avoid tax obligations (Wex, 2016); while tax elusion (tax avoidance) is the act of using legal strategies (e.g. loopholes, ambiguities in the legal texts) to avoid taxation. The former is considered a crime, while the latter is not; both reduce tax revenue and opportunities to create fiscal space for social pensions.

Macroeconomic principles warn against the negative, destabilizing impact on business cycles as a result of an increase in tax rates. Raising taxes, it is argued, reduces individual and corporate disposable income because they -individuals and corporations - must use part of their profits to accommodate the increase. These principles also argue that tax hikes and a reduction in disposable income would correspondingly reduce aggregate demand in the economy. In macroeconomic terms, a reduction in aggregate demand would shift the demand curve to the left and this will negatively impact real GDP in the short run. In theory, personal consumption expenditure and fixed investment should be the two components of GDP, with the greater direct impact due to tax rate increases. In simple words, if individuals have to pay more taxes then they will have less space to invest and to buy goods and services in the economy.

However, it is important to recall that not all tax increases affect all individuals in a society. If governments are able to identify a progressive way of increasing taxes, tax revenues could be used to redistribute income. In the case of social pensions, revenue raised via taxes can be transferred to one of the most vulnerable segments of the population, and one which is comprised of arguably the most apparent manifestation of past state building: older individuals. Social pensions would then provide an income replacement for old-age population, directly spent and/or invested back into the economy.

In the long-run, the supply of money transferred from one segment of the population to the old-age population as a redistributive measure would not impact negatively on real GDP. On the contrary, if resources are allocated to vulnerable sectors who spend a large -if not total - amount of their disposable income on goods and services, the redistribution of income via tax-funded social pensions could increase personal consumption expenditure and even fixed investment. As a result, the demand curve would shift towards the right. A recent study of the Philippine social pension found that state funded social pensions accounted for nearly 30 per cent of household income and had 'some impact on the expenditure of recipient households [e.g. food, bills, education and clothes], particularly on health expenditures' (Knox-Vydmanov, Horn, \& Sevilla, 2016, p. 31). Across the 
Pacific, the 2011 EPAM national survey in Bolivia reveals that - on average - beneficiaries of the social pension Renta Dignidad spent more than half of the transfer on food, followed by expenditures on health and utilities (Mendizábal \& Escobar, 2013). These are just two examples of how income transfers to old-age population can stimulate the economy rather than destabilize the business cycle.

The following sections examine three possible ways in which governments can increase tax revenues, creating fiscal space to fund social pensions.

\subsection{Income Tax}

Income tax - i.e. levies on individual or household income - are generally considered direct taxes. ${ }^{5}$ These include personal incomes after deductions, such as employee compensation (e.g. wages, salaries), property income (e.g. interests, rent) and pensions (e.g. taxable portions of any public or private retirement benefit) (IMF, 2014, p. 91).

This type of direct tax is generally considered progressive, meaning that individuals with higher incomes contribute more to government tax revenue than individuals with lower incomes. Such tax codes make implicit distinctions between 'richer' and 'poorer', taxing the former more than the latter, generally speaking.

However, increasing revenues via direct taxation in low- and middle-income countries is not a simple matter. The large proportion of those working in the informal sector marks a significant barrier to the realization of direct taxation. ${ }^{6}$ The effectiveness of revenue collection via direct taxes is positively related to the size of the formal economy (i.e. the larger the size of the population working in the formal sector, the larger the share of contributors). Figure 5 shows the population shares across 33 countries employed in the informal economy. Around 84.9 per cent of those countries with available data exhibit a level of informality higher than 40 per cent (i.e. 2 out of 5 workers are employed in the informal economy). This figure of informality rises to 50 per cent in approximately 66.7 per cent of the countries (i.e. 1 out of 2 are employed in the informal economy).

\footnotetext{
${ }^{5}$ According to the OECD (2014), direct taxes on income 'are levies by public authorities at regular intervals, except social contributions, on income from employment, property, capital gains or any other source'. The IMF Government Finance Statistics database includes taxes deducted by employers (pay-as-you-earn taxes) and surtaxes.

${ }^{6}$ The ILO defines employment in the informal economy 'as the sum of employment in the informal sector and informal employment found outside the informal sector' (ILO, 2012).
} 
To illustrate the ramifications of informality, let us imagine an economy with 100 workers, each making 1000 pounds in wage. The level of informality in this economy is 84.2 per cent - as in India (see Figure 5). The direct tax (e.g. income tax) burden on labour income is 20 per cent, and the Ministry of Finance/Treasury have a 100 per cent rate of tax collection. Hypothetically, this economy would be collecting around 3160 pounds in tax revenues. The loss of revenue from informality would amount to (all things being equal) 16840 pounds. Or to put this in another way, for every worker incorporated into the formal economy, public revenues would increase by 200 pounds. This is equivalent to a 6.3 per cent relative increase according to the initial hypothetical tax revenues, with 84.2 per cent of the population working in the informal economy. Of course, real national economies are immensely more complex. However, our thought exercise illustrates the substantial fiscal costs of high levels of informality in the (world) economy.

\section{-Figure 5-}

There is no doubt that a high ratio of workers in the informal sector is a huge limitation to create fiscal space via income tax - i.e. an increase in the income tax burden would fall only on the shoulders of workers in the formal sector. However, there are considerable differences among countries in terms of minimum, maximum, and marginal tax rates. According to the latest data, eleven countries in the world have a zero income tax rate ${ }^{7}$, while twelve countries ${ }^{8}$ have a tax rate equal or over 50 per cent for the top income bracket. Approximately 79 per cent of the countries in the sample (110 of 140) have a top marginal tax rate lower than the 2015 OECD average (41.7 per cent) (KPMG, 2015). It is difficult to justify that there is little room to manoeuvre to increase revenues and create fiscal space by increasing the income tax rates on the wealthiest groups of the population.

For example, using data from the Tax Policy Center, the United States could be able to create around US\$157 billion ( 0.9 per cent GDP) of fiscal space by raising the income tax burden of the top 1 per cent to 40 per cent. Increasing the tax burden to 45 per cent, an additional US\$ 276 billion (1.6 per cent GDP) could be generated and (ideally) used to finance social protection (Cohen, 2015). ${ }^{9}$ The latter example could create fiscal space to

\footnotetext{
7 Anguilla, Bahamas, Bahrain, Bermuda, Brunei Darussalam, Cayman Islands, Kuwait, Oman, Qatar, Saudi Arabia, and United Arab Emirates (data is for 2015 or the most recent value).

${ }^{8}$ Austria, Aruba, Belgium, Denmark, Finland, Israel, Japan, Netherlands, Senegal, Slovenia, Sweden, Zimbabwe (data is for 2015 or the most recent value).

${ }^{9}$ Recent work from the Brookings Institution argues that increasing the top personal income tax rate in the United States from 39.6 to 50 per cent would bring in an additional 95.6 billion US\$ (around 0.55 per cent GDP) (Gale, Kearney, \& Orszag, 2015). Therefore, this figure is smaller -although significant- in comparison to the ones using data from the Tax Policy Center.
} 
fund approximately 77 per cent of a hypothetical basic universal social pension for everyone above 70 years and with a pension level 20 per cent of GDP per capita. To take another example, Singapore could expect to generate around US\$ 294 million a year by raising the personal income tax of the top 5 per cent of earners from 17.9 to 19.5 (Asia News Monitor, 2015). This increase would potentially create a fiscal space equivalent to 0.9 per cent of GDP and could fund approximately 61 per cent of a hypothetical basic universal social pensions for everyone above 70 years and with a pension level 20 per cent GDP per capita.

The question we are then interested in, especially as it pertains to fulfilling the redistributive functions of social protection, is the extent to which such policies might facilitate increases in public spending towards inequality and poverty reduction. Figure 6, using data from the World Wealth and Income database (Alvaredo, Atkinson, Piketty, Saez, \& Zucman, 2016), estimates the potential impact which an increase in tax rates on the richest individuals in 22 middle- and high-income countries would mean for social protective functions of the state. The formula proposed by Piketty, Saez, and Stantcheva (2011b) is used to calculate the potential fiscal space generated by increasing the tax rates of the top 1 per cent and top 5 per cent income share; given as:

$$
F s=i s_{x} t
$$

Where $F s$ is the fiscal space created - in percentage points of GDP, $i$ is the total market income reported for tax purposes - in percentage points of GDP, $s$ is the income share of the top $x$ per cent excluding capital gains - in this case the top 1 and 5 per cent, and $t$ is the tax rate experimental increase - in percentage points. ${ }^{10}$

Figure 6 shows the potential fiscal space of both scenarios - increasing tax rates of the top 1 and 5 per cent. On average, an increase in 5 percentage points on the average tax rate of the richest 1 per cent creates a fiscal space equivalent to 0.3 per cent of GDP, 0.6 per cent of GDP for an increase in 10 percentage points, and a fiscal space equivalent to 1.2 per cent of GDP for an increase in 20 percentage points. The same three tax rate increases on the richest 5 per cent creates, on average, a fiscal space equivalent to $0.6,1.3$, and 2.5 per cent of GDP.

\section{-Figure 6-}

\footnotetext{
${ }^{10}$ The most recent data in the World Wealth and Income database is used.
} 
What does this 5, 10 and 20 percentage point increase represent in terms of the actual top tax rate? On average, an absolute 5, 10 and 20 percentage point increase is equal to a relative increase of 14.2, 28.3 and 56.6 per cent in the current top tax rate. As it may be expected, countries with the lowest top income tax rate (e.g. Mauritius and Singapore) are those with the highest relative increase in this analysis. Critics might highlight the supposedly negative economic effects such increases might entail, as lower top income tax rate would promote higher economic growth. However, Piketty et al. (2011b) show that - since the $1970 \mathrm{~s}-$ top income tax rate cuts in high-income countries have had no correlation with economic growth (average annual real GDP per capita growth). Others may argue that higher top income tax rates may increase tax avoidance, decrease productivity, work effort and business creation (Engen \& Skinner, 1996; Feldstein, 1995). Nonetheless, even after considering these negative externalities the optimal top income tax rates are between 57 per cent and 83 per cent (Piketty, Saez, \& Stantcheva, 2011a). ${ }^{11}$ Therefore, if this conclusion were extrapolated to the actual analysis, none of the 22 countries in the sample would surpass the 83 per cent barrier.

Garfinkle (2005) discredited supply-side economists' claims that there is a positive correlation between lowering top income tax rates and an acceleration in the economic growth, employment growth and investment growth. In the researcher's own words, “a review of 'large body' of theoretical literature on the subject shows the empirical evidence supporting this claim to be sparse to non-existent" (Garfinkle, 2005, p. 429). Highincome countries had experience a similar growth rate during the last 4 decades, despite having significant variations in the top-income tax rates (Alvaredo, Atkinson, Piketty, \& Saez, 2013, p. 11). Therefore, Alvaredo et al. (2013) have not found any significant correlation between cuts in the top-income tax rates and economic growth (measured as real GDP per capita). Gale, Krupkin, and Rueben (2015) recently reconfirmed the nonexistence causal relationship between lowering top-income tax rates and the generation of significant impacts on economic growth and employment growth. As it has been show in several publications, reducing top income tax rates is not expected to produce significant macroeconomic imbalances, however it is expected to continue having a significant effect on the top income dispersion (i.e., continue increasing the gap between the top 1 per cent and the rest of the working population) (Nirei \& Aoki, 2016).

"By contrast, there is substantial evidence for the demand-side view that high personal consumption expenditures (the largest component of aggregate demand) are associated with high growth in GDP,

\footnotetext{
${ }^{11}$ Kinderman and Krueger (2014) argued the optimal top income tax -for the US- would be close to 90 per cent. Future studies should replicate these studies in low- and middle-income countries in order to estimate an optimal tax rate.
} 
employment, and investment" (Garfinkle, 2005, p. 445). Increasing taxes to the top-income earners and distributing it via social pensions could be part of increasing the aggregate demand. A "demand-side approach to taxation policy" as Garfinkle argues, is expected to increase personal consumption of older-age population and their families and in return it would facilitate higher economic, employment and investment growth rates. The question is whether the results shown in the last two paragraphs would also be witnessed in low- and middleincome countries. However, the existence or not of considerable heterogeneity across countries in different development stages needs to be conformed in future research.

Going back to the results shown in Figure 6, what is the funding power of the fiscal space created after raising the top 5 per cent income tax rates in 10 percentage points? China would be able to finance 36.3 per cent of a basic social pension for everyone above 70 years of age and with a pension level equivalent to 20 per cent GDP. This same increase would allow Uruguay to finance 66 per cent of a similar basic social pension, while Mauritius and Malaysia would be able to finance 61.4 and 87.6 per cent of a basic social pension with an eligibility age of 65 .

While examples abound, the question is whether governments around the world would increase the tax burden of the top earners - fundamentally a politically charged issue. As the example of the United States and Singapore reveal, this could be (relatively) an easily implemented first step to increase fiscal space while using other instruments - e.g. the Uruguayan Monotax scheme ${ }^{12}$ - to encourage the formalization of workers in the informal sector. The options available to policymakers remain myriad, however the use of this component of direct taxation is a clear example of a possibly straightforward and politically viable choice. The reason is simple, if top income represents a "very significant share of total income and total taxes paid" (Atkinson, Piketty, \& Saez, 2011, p. 3), then the revenues deriving from an increase of top-income tax rate could also be very significant and could be used for redistribution purposes.

\footnotetext{
12 According to Durán-Valverde (2014) the Uruguayan Monotax is a simplified taxation system that combines social security provision. The Monotax was created in 2001 and modified in 2007 to increase the number of freelancers and workers in the informal sector in the social security scheme. In just three years after the modification the number of workers and firms in the social protection scheme has tripled. See Durán-Valverde (2014) and Amarante and Perazzo (2013) for more details on the Monotax.
} 


\subsection{Corporate Tax}

Income taxation aside, corporate tax represents yet another example of direct taxation options available for governments. In this case it is levied on the profits of a firm/corporation - after depreciation. ${ }^{13}$ As with income taxes, economic ideology plays an important role on levies on corporate profits/incomes worldwide. Against the backdrop of 'trickle-down economics', many economists and governments have argued in favour of low corporate taxation to promote growth and employment. ${ }^{14}$ Taxes (generally) are perceived as disincentives for entrepreneurship, risk taking, and the creation of national wealth and jobs. This explains (partially) why taxes on corporations and high-income earners have been cut since the 1980's; implemented also across low- and middleincome countries. Thirty-four countries have lowered their top income tax rates from $2010^{15}$ to 2014 , and 5 countries have made major cuts - over 25 per cent - on corporate income taxes between 2005 and 2010 (Ortiz et al., 2015, pp. 12-13).

In fact, in times of low corporate tax economies are growing at an unprecedented rate. But, who is benefiting the most from that economic growth? Here recent research by Oxfam provides a stark reminder of the perils of noninclusive growth models:

'In 2015, just 62 individuals had the same wealth as 3.6 billion people - the bottom half of humanity. This figure is down from 388 individuals as recently as 2010 . The wealth of the richest 62 people has risen by 44 per cent in the five years since 2010 (...) Meanwhile, the wealth of the bottom half fell by just over a trillion dollars in the same period - a drop of 41 per cent' (Hardoon, Fuentes-Nieva, \& Ayele, 2016, p. 2).

Tax systems are fundamentally well positioned to fund welfare policies, redistribute income, and promote equal opportunities for all. In the case of social pensions, such revenue mobilization and redistribution is uniquely to fund programs which redistribute incomes towards older persons - not least where the deficit of past

\footnotetext{
13 The IMF Government Finance Statistics database includes taxes on 'the income of units such as partnerships, sole proprietorships, estates, and some trusts that are recognized as corporations. This covers income from all sources and not simply profits generated by production' (IMF, 2014, p. 91).

${ }^{14} \mathrm{By}$ this logic, economic gains will eventually 'trickle-down' to the rest of the population making everyone better off in absolute terms (Chang, 2014, pp. 318-319). However, Piketty et al. (2011a) find a strong correlation between cuts in top tax rates and increases in the income share of the highest earners (top 1 per cent), working against the principles of inclusive growth.

${ }^{15}$ Authors used the average rate for the years 2010-2013.
} 
government policies induce inequality and disadvantage at the end of the life-course. Such income security guarantees lessen the impact of the accumulation of (non-random) disadvantages and inequalities of old-age individuals

Often used as an incentive attracting foreign (multinational) firms, low corporate tax rates are more often than not seen as a catalyst for promoting economic activity, employment and increasing aggregate demand. This is particularly pernicious in an era where the focus is on sustainable national systems, where many countries have considerably low corporate tax rates, while others impose no tax on corporations. In 2015, 9 countries existed with zero corporate tax rates ${ }^{16}$, and several others exhibiting minimal tax rates. Such situations foster the phenomenon of corporate tax havens, starving many countries from much needed resources to achieve their fiduciary obligations. ${ }^{17}$

The losses incurred from such activities are not inconsequential for development. According to Action Aid, Zambia (for example) loses over US\$ 13.8 million (Zambian Kwacha 62 billion) a year to tax havens from a single firm - Zambia Sugar Plc.; itself a subsidiary of multinational Associated British Foods (Lewis, 2013, p. 2). To put this in context, US\$ 13.8 million is the equivalent of 0.05 per cent of 2014 GDP - the same amount required to fund approximately 25 per cent of a hypothetical basic universal social pensions for all citizens above $75+$ at 20 per cent GDP per capita. According to Citizens for Tax Justice (2016), 303 Fortune 500 companies hold around US\$2.4 trillion offshore, arguing that such revenue is 'permanently reinvested'. This is particularly as this entails that these companies may be avoiding up to US\$ 695 billion in US Federal corporate taxes. ${ }^{18}$ This is equivalent to nearly 4 per cent of US GDP in 2014 - the amount required to fund approximately 128 per cent of a hypothetical basic universal social pensions for everyone $65+$ at 20 per cent GDP per capita.

According to Zucman (2015), at least US\$ 7.6 trillion is 'missing' or hidden in tax havens and other vehicles for tax evasion. Taking that estimate to be true, global revenue loss to offshore tax evasion is at least US\$ 190 billion. Europe (US\$ 78 billions), United States (US\$ 35 billions) and Asia (US\$ 34 billions) are the most

\footnotetext{
${ }^{16}$ Bahamas, Bahrain, Bermuda, Bonaire, Saint Eustatius and Saba, Cayman Islands, Guernsey, Isle of Man, Jersey, Vanuatu

${ }^{17}$ Corporate tax havens are fiscal homes to corporations operating worldwide, using tax loopholes or practices such as transfer pricing to evade/avoid paying the corresponding amount of burden. These practices deprive countries worldwide of collecting revenues from profits made on their own territories.

${ }^{18}$ According to Citizens for Tax Justice (CTJ), only 55 corporations disclosed the U.S. tax rate (28.6 per cent) they would pay if offshore profits were repatriated. CTJ estimated the value of corporate tax revenues lost to tax havens by using the same average tax rates ( 28.6 per cent) on the 248 non-disclosing companies (Citizens for Tax Justice, 2016).
} 
affected. The recent leakage of the Panama Papers - 11 million documents from the law firm Mossack Fonseca would reveal more names of corporations and individuals using tax havens to hide wealth and presumably evade tax.

Now, how to solve this problem of corporate tax dodging and transfer mispricing ${ }^{19}$ ? Implementing a global corporate tax rate is not an easy thing to do. The Tax Justice Network has proposed the unitary taxation system as a way of taxing transnational corporations according to the genuine profits made in each country where they did business. ${ }^{20}$ Countries would be able to tax corporations for the genuine share of revenues made inside their national borders. For example, if corporation X made 50 per cent of profits/payroll/assets in country Y, 49 per cent of profits/payroll/assets in country Z, and 1 per cent of profits/payroll/assets in a tax haven then corporation $\mathrm{X}$ would have to pay corporate taxes in each country according to the shares of profits/payroll/assets made/spent/owned in each. Currently, however, many are able to use practices such as transfer mispricing to manipulate the value of outputs traded among subsidiaries ${ }^{21}$, thus allowing some of them to redirect profits to tax havens with lower corporate tax rates. National transparency laws, mandatory disclosure of global revenues -including all subsidiaries -would facilitate greater transparency and mitigate loss due to corporate and individual profit relocation towards tax havens.

\subsection{Trade tax (import/export tariffs)}

Trade taxes are levied when outputs cross national borders (exports or imports of goods and services). The IMF Government Finance Statistics database classifies trade taxes 'into various subcategories according to the nature of the exchange and whether the exchange is related to imports or exports' (IMF, 2014, p. 100).

In the actual globalized world, countries exhibit a high level of connectedness and interdependence. Since the last two decades of the twentieth century, trends have emerged aimed at reducing trade barriers worldwide.

Orthodox economists have argued in favour of free trade as an essential ingredient for economic growth, income

\footnotetext{
19 Transfer mispricing -also known as transfer pricing manipulation- occurs when two subsidiaries of the same multinational group 'artificially distort the price at which the trade is recorded, to minimise the overall tax bill' (Tax Justice Network, n.d.).

${ }^{20}$ Sales, payroll and/or physical assets could be used as proxies in a formula to estimate the genuine profits/share of revenues in each country. See Picciotto (2012) for further details on the unitary taxation system and Picciotto (2015) to access the 8 outputs produced in a research programme financed by the international Centre for Tax and Development.

${ }^{21}$ Highly important as 'more than $60 \%$ of world trade takes place within multinational enterprises' (Neighbour, 2008).
} 
poverty reduction, and for the creation of labour-intensive jobs in the long-run (Bhagwati \& Srinivasan, 2002; Froning, 2000; Moreira \& Najberg, 2000). However the United Nation's Economic Commission for Latin America and the Caribbean (ECLAC) have argued that in order to experience such positive trade effects, several factors and policies are required. For example, $\operatorname{ECLAC}(2014$, p. 46) argues that trade can facilitate growth if internal and external structural heterogeneities are reduced and national policies effectively stimulate small and medium enterprises to increase their competitiveness and productivity. However, in the search for productivity and competitiveness, trade liberalization and openness may produce negative effects in the quantity and quality of available jobs and, as a consequence, impact negatively on the income security of the working population. Scholars such as Frankel and Romer (1999) find no evidence to suggest the causation effect of trade on growth although they did find a moderately statistically significant positive effect on income.

More relevant is the argument raised by Mkandawire (2005), 'often the most widely applied taxes and the easiest to collect (for example, taxes on trade) are removed as part of the adjustment policies' and trade liberalization. Subsequently, the lack of government revenues in low- and middle-income countries have often been used as a pretext to cut social spending and social security programmes due to fiscal crisis. The fact is that high-income countries have been able to replace trade tax revenues with domestic tax revenues, while middleand low-income countries have not. According to IMF researchers Baunsgaard and Keen (2010), middle-income countries have been able to replace between 35-50 per cent of trade tax revenues in the short run and almost 100 per cent in the long run with domestic tax revenues. Meanwhile low-income countries have only been able to replace between 20-25 per cent of trade tax revenues with domestic taxes in the short run. Therefore, trade liberalization has been hindering government sources of revenues. Liberalization of trade tax is not in and of itself, but the timing of the degree of implementation is critical. Furthermore, it may be that where liberalization is hurting the build-up of domestic revenue generation/collection capacity, it will be the dogmatic approach to rigid ideology that is thwarting the goals which its proponents are (at least publicly) adamant on.

Are trade tax rates too low for some low- and middle-income countries?

To examine this question, tariff data from the WTO (2016) is used to compare the average tax on imports (goods) as a percentage of the import value (simple average applied MFN tariff) against the simple average bound tariff (BT) - the tariff rate ceiling agreed with the WTO. This simple comparison allows identifying how many countries have room to increase tariffs (and by extension, revenues) and thus create fiscal space for social 
pensions. Only 14 per cent (19 of 132) of cases surpassed the BT agreed with the WTO. ${ }^{22}$ Accordingly, increasing tariffs might be a solution to increase fiscal space in 86 per cent (113 of 132) of the countries in the sample. In addition, 82 countries have tariffs below the average of the sample ( 38.8 per cent), and 66 below the median (30.2 per cent).

Ortiz et al. (2015, p. 17) argue for the examination of tariff levels ${ }^{23}$, 'at least until domestic tax collection mechanisms are strengthened to sustain or increase levels of [government] revenue'. This point raises a crucial position, one which has implications for countries which may want to increase tariffs without producing macroeconomic imbalances, specifically inflation and a decrease in the aggregated demand due to higher costs of imports goods. Countries importing large shares of intermediate goods should be examined on a one-to-one basis, in order to prevent negative externalities on the level of competitiveness of national industries.

Revenue generation through tariff increases

Because of the different realities of countries worldwide (e.g. exporting versus importing countries), identifying common thresholds for tariffs is problematic. However, this section examines the hypothetical fiscal space that could be created by increasing tariffs by - an experimental ${ }^{24}$ - 5 and 10 per cent. The analysis includes 81 of the 82 countries with a simple average applied MFN tariff below the sample mean. ${ }^{25}$ Data for imports of goods and services (percentage of GDP) comes from the CEDLAS and Bank (2016).

An increase of 10 per cent in the tariffs of goods and services, ceteris paribus, would enable an average fiscal space of 0,9 per cent of GDP (See Figure 7 for country specific projections). Examining the potential funding power of this fiscal space on social pensions:

- Namibia, Central African Republic and Maldives would be able to finance a basic universal social pensions for everyone above 50 years and with a pension level equivalent to 20 per cent GDP;

- Cambodia and El Salvador would be able to finance more than 90 per cent of a similar basic universal social pension;

\footnotetext{
${ }^{22}$ Burkina Faso, Congo, Malawi, Burundi, Uganda, Zimbabwe, Togo, Myanmar, Chad, Cameroon, Ghana, Kenya, Mauritius, Mozambique, Gambia, Zambia, Nigeria, Tanzania and Bangladesh.

${ }^{23}$ The WTO defines tariffs as custom duties on merchandise imports.

${ }^{24}$ Therefore, this paper is not recommending raising tariffs by 5 per cent or 10 per cent. The countries selected have the space to increase tariffs if the average, the mean and the WTO-bound are used as a threshold.

${ }^{25}$ Chinese Taipei is excluded due to unavailability of imports data.
} 
- Congo and Papua New Guinea would be able to finance more than 80 per cent of a similar basic universal social pension;

- Honduras and Senegal would be able to finance more than 70 per cent of a similar basic universal social pension.

Again, these are tentative numbers; however, they do bring to the fore the potential (and significant) funding power of tariffs.

\section{EXAMINING THE FUNDING POWER OF INCREASING TAX REVENUES}

This paper has analysed possible options for creating fiscal space via increasing top income tax rates, taxing corporate profits appropriately, and increasing tariffs modestly. These are just a few examples of how countries could create fiscal space for financing social protection and social assistance programmes - specifically social pensions. Additional fiscal space can be facilitated through a multiplicity of sources. However, what may seem as an efficient option for some cases may be inefficient for others - while the specificities of approach are matters for debate, the reality of the need for greater domestic resource mobilization is not.

\section{-Figure 7-}

The purpose of this section is not to identify additional options for creating fiscal space, but to examine the potential funding power of increasing tax revenues. Three scenarios are scrutinized with a sample of 20 lowincome countries, 38 lower-middle-income countries and 38 upper-middle-income countries. Scenario 1 presents the potential fiscal space created by increasing tax revenues ${ }^{26}$ by 5 per cent. Indirect taxes (e.g. VAT, sales tax) are excluded as increasing this (regressive) tax would directly affect the consumption capacity of older persons. ${ }^{27}$ Scenario 2 illustrates the potential fiscal space created by increasing direct taxes (i.e. income and corporate taxes) by 10 per cent. Finally, scenario 3 presents the potential fiscal space created by increasing

\footnotetext{
${ }^{26}$ The following taxes where considered: taxes on income, profits and capital gains, taxes on payroll and workforce, taxes on property, taxes on financial and capital transactions, excise taxes, taxes on trade and transactions and other taxes considered on the IMF Government Finance Statistics database under the 116 category.

${ }^{27}$ For example, if a large part of older-age people's income is used to buy goods and services (e.g. groceries, housing, medicines) then an increase in consumption tax would directly reduce their disposable income. If John earns 100 pounds and spend all of it on taxable goods and services, an increase in the consumption tax rate would reduce John's capacity to buy groceries, medicines and other goods and services. Thus, an increase in consumption tax rate is regressive as it affects more those earning the least and spending the largest part of their incomes in consumption outputs.
} 
excise taxes and taxes on financial and capital transactions by a much greater 20 per cent. Tax revenue data comes from the IMF (2016) Government Finance Statistics database. The cost of social pensions is calculated using the latest age-disaggregated data from the United Nations Population Division (UNPD, 2015). ${ }^{28}$

Figure 8 illustrates three potential scenarios for universal social pensions with a pension level of 20 per cent GDP per capita, and an eligibility age of 75 (first level), 70 (second level) and 65 (third level). Low-income countries in scenario 1 stand to benefit the most, with all countries generating enough fiscal space to provide a basic social pension for everyone above 75 years of age. Seventy-per cent would be able to fund a social pension with an eligibility age of 70 , and 65 per cent would be able to finance at least 70 per cent of the social pension cost for everyone above 65 years. Meanwhile a tax revenue increase would have a relatively lower impact funding social pensions in upper- and lower-middle-income countries. Nevertheless, a 5 per cent increase in tax revenues would be enough to finance basic social pensions for everyone above 75 years of age in 23 lower-middle income countries, while 18 upper-middle-income countries would be able to finance at least 80 per cent of the social pension (See solid line in Figure 8).

The potential impact of increasing just two direct taxes is promising. Under the assumptions presented, increasing direct taxes revenues by 10 per cent would create enough fiscal space to fund social pensions for every individual above 75 years of age in 75 per cent of low-income countries, 53 per cent of lower-middleincome countries and 39 per cent of middle-income-countries. On average, the financing capacity would be equivalent to 78 per cent of the cost of social pensions for everyone above 70 years of age, and around 47 per cent of the social pension's cost with an eligibility age of 65 (See dotted line in Figure 8). As mentioned earlier, a relevant issue to take into account is that the share of personal income tax revenue could be increased not only by increasing the marginal tax rates, but also by increasing the number of taxpayers (reducing informality).

The funding power of increasing tax revenues by 20 per cent on financial transactions and excise taxes is also significant by itself - although not as much as the previous scenario. This could potentially generate enough revenues to finance social pensions for every individual above 75 years of age in 55 per cent of low-income countries, 32 per cent of lower-middle-income countries, and 18 per cent of middle-income-countries. On

\footnotetext{
${ }^{28}$ This paper used the same methodology presented in a previous brief policy paper (Cruz-Martinez, 2016) to estimate the cost of social pensions in 96 low- and middle-income countries. A modified version of Willmore's (2007) formula was used, adding the 5 per cent of the total cost of transfers as administrative cost [previously proposed by Knox-Vydmanov (2011, p. 3)].
} 
average, the funding power of increasing these tax revenues would be equivalent to 47 per cent of the cost of social pensions with an eligibility age of 70 years, and around 29 per cent of the cost of social pensions for everyone above 65 years of age (See dashed line in Figure 8).

\section{-Figure 8-}

Several cases deserve focused attention:

- For Zimbabwe, Liberia and Mozambique, a 5 per cent increase in total tax revenues - excluding consumption taxes, and a 10 per cent increase in direct taxes, could conceivably create enough fiscal space to cover the costs of social pensions for everyone above 65 years - with revenues remaining to invest in other social programmes or increasing the pension level.

- Increasing total tax revenues and direct tax revenues does not create enough revenues to finance social pensions for everyone above 65 years in Burundi and Uganda. However, an increase in revenues from financial transactions and excise taxes creates ample fiscal space to fund this pension.

- The Solomon Islands could potentially fund social pensions for everyone above 65 years in scenario 1 and 2. Nevertheless, tax revenues from financial transactions and excise taxes have the potential to fund by itself social pensions with an eligibility of 70 years.

- In countries like Laos and Samoa, only by increasing tax revenues from scenario 3 creates the hypothetical requisite fiscal space to cover almost the total cost of social pensions for everyone above 65 years of age.

- Algeria is the only country where the revenues from all scenarios are enough to fund social pensions with an age eligibility of 65 .

- Turkey is the only upper-middle-income country where tax revenues from scenario 3 have a potential funding power of a social pension program for everyone above 70 years. Meanwhile, additional estimated revenues from scenario 1 and 2 would only be sufficient to fund a social pension with an eligibility age of 75 .

- Revenues from direct taxes would potentially be able to finance a social pension with an eligibility age of 65 in Angola, Namibia and South Africa, and with an eligibility age of 75 in Tunisia, Suriname and Jamaica. In all countries, scenario 2 creates the most fiscal space. 
This section examined the funding power of increasing tax revenues. However, there are several cases in the sample exhibiting actual tax revenue of (near) zero. An increase in tax rates and/or an increase in the state capacity of collecting taxes would inevitably be taken into account in order to be able to increase revenues. Ten countries exhibited (near) zero tax revenues from income and corporate taxes. This figure rises to 21 regarding tax revenues from financial and capital transactions and excise tax.

\section{POLITICAL ISSUES: AGENDA-SETTING AND AGENDA-BUILDING OF TAX REFORM}

The literature shows several ways in which progressive tax reforms can be placed in the political agenda. The case of Chile's tax reform in 2012 and 2014 highlight the role of social movements and the media in placing the tax reform issue in the political agenda. As Letelier S and Dávila A (2015) argued, tax reforms in Chile were explicit responses to the demands from social movements to improve the public education. According to the researchers, the incorporation of the student's demand in the political agenda "was mainly a response to the role of the media, the fact that it is not difficult for students to organise themselves and express their demands, the support of students' families and the [former conservative Alianza] government's fear of missing out on a second term in office” (Letelier S \& Dávila A, 2015, p. 832).

Moving policy sentiment toward a progressive tax reform to fund social pensions may be understood as responses in the economic expectation of the population. After using a multiple-time series error correction model for a two decades' period in the United States of America, Durr (1993) confirms that expectations of a strong economic performance result in greater support for liberal domestic policies - such as progressive tax reforms. In addition to the need of setting the tax reform issue on the political agenda, it is also relevant to mention the need to increase the support for redistributive policies. According to Lester (2011, p. 1), universalist programmes - in contrast to means-tested programs - "plausibly increase preferences for redistribution by tapping social norms of reciprocity, generating group identity effects based on a sense of common vulnerability, and serving as a "policy frame" that de-emphasizes the salience of low-income people as an undeserving 'out-group"'. Universal social pensions can therefore be more successful in gaining support than means-tested social pensions. 


\section{CONCLUSION}

This paper examined three alternatives to create fiscal space for social pensions via tax revenues. First, it concludes that increasing the top income tax rates for the richest 1 per cent or 5 per cent could create a significant amount of fiscal space. For example, an increase of 10 percentage points in the top income tax rate of the top 1 per cent creates on average 0.6 per cent GDP. This figure is increase to 1.3 per cent if the top 5 per cent is considered. Negative externalities of these tax increases are expected to be minor as optimal top income tax rates are between 57 per cent and 83 per cent.

Second, corporate tax is one source that could be used to finance social pensions. This paper highlighted the large amount of revenues (US\$ 190 billion) that are 'missing' or hidden in tax heavens, as well as some of the tools corporations used to evade taxes. International cooperation, transparency laws and global corporate tax are some of the options to reduce evasion and increase government revenues for social protection and other public expenditures.

Trade tax is the third option analysed in the paper. During the last decades of neoliberalism and liberalization, low-income countries have not been able to replace revenues from export and import tariffs. After analysing the actual tariffs of 132 countries in relation to the tariff rate ceiling agreed with World Trade Organization, the paper concludes that increasing tariffs might be an initial solution to increase fiscal space in 86 per cent of countries in the sample. The potential fiscal space can start funding -totally or partly- basic universal pensions in several countries.

The last section examines the potential funding power of increasing tax revenues, direct taxes, and, excise taxes and taxes on financial and capital transactions. The results are promising for most of the countries, although it is important to remember that there is no common prescription for all.

Future papers should examine the funding power of other sources to create fiscal space for social pensions. The list in the introduction named a few of general options, but each country should examine their budgets, revenues and expenses to propose native solutions to a global problem. Older age population deserve well-being, and political will is the key to start looking for options. 
Funding: This study was funded by Help Age International, while the author was a Research Fellow.

Ethical approval: This article does not contain any studies with human participants performed by any of the authors.

Informed consent: Informed consent was obtained from all individual participants included in the study.

\section{References}

Alvaredo, F., Atkinson, A. B., Piketty, T., \& Saez, E. (2013). The Top 1 Percent in International and Historical Perspective. The Journal of Economic Perspectives, 27(3), 3-20.

Alvaredo, F., Atkinson, A. B., Piketty, T., Saez, E., \& Zucman, G. (2016). The World Wealth and Income Database. http://www.wid.world, 22/03/2016.

Amarante, V., \& Perazzo, I. (2013). Trabajo por cuenta propia y monotributo en Uruguay. Serie de Documentos de Trabajo, Instituto de Economía, Universidad de la República, 4/13.

Asia News Monitor. (2015). Singapore to raise income tax for top earners. February 26, Bangkok.

Atkinson, A. B., Piketty, T., \& Saez, E. (2011). Top Incomes in the Long Run of History. Journal of Economic Literature, 49(1), 3-71.

Barrientos, A., \& Niño-zarazúa, M. (2011). Financing Social Protection for Children in Crisis Contexts. Development Policy Review, 29(5), 603-620. doi:10.1111/j.1467-7679.2011.00549.x

Bastagli, F. (2015). Bringing taxation into social protection analysis and planning. ODI Working Paper, 421: https://www.odi.org/sites/odi.org.uk/files/odi-assets/publications-opinion-files/9700.pdf.

Bastagli, F. (2016). Bringing taxation into social protection analysis and planning. Guidance Note. London: ODI: https://www.odi.org/sites/odi.org.uk/files/resource-documents/10387.pdf.

Baunsgaard, T., \& Keen, M. (2010). Tax revenue and (or?) trade liberalization. Journal of Public Economics, 94(9-10), 563-577.

Bhagwati, J., \& Srinivasan, T. N. (2002). Trade and Poverty in the Poor Countries. The American Economic Review, 92(2), 180-183.

CEDLAS, \& World Bank (2016). Socio-Economic Database for Latin America and the Caribbean. http://sedlac.econo.unlp.edu.ar/eng/.

Chang, H.-J. (2014). Economics: The User's Guide. London: Penguin Books.

Citizens for Tax Justice. (2016). Fortune 500 Companies Hold a Record \$2.4 Trillion Offshore. http://ctj.org/pdf/pre0316.pdf.

Cohen, P. (2015). What Could Raising Taxes on the 1\% Do? Surprising Amounts. The New York Times, October 16: $\quad$ http://www.nytimes.com/2015/10/17/business/putting-numbers-to-a-tax-increase-for-therich.html? $r=0$.

Cruz-Martinez, G. (2016). Means Testing vs. Universal Targeting Assumptions of Efficiency and Affordability. Pension watch briefing series, HelpAge International(15: http://www.helpage.org/download/57d132ef8f8f9).

Durán-Valverde, F. (2014). Monotax: Promoting formalization and protection of independent workers. Social Protection in Action: Building Social Protection Floors, 2, International Labour Office.

Durán-Valverde, F., \& Pacheco, J. F. (2012). Fiscal space and the extension of social protection: Lessons learnt from developing countries. Extension of Social Security Working Paper, 33, International Labour Organization.

Durr, R. H. (1993). What Moves Policy Sentiment? The American Political Science Review, 87(1), 158-170. doi: $10.2307 / 2938963$

ECLAC. (2014). International trade and inclusive development. Building synergies. Santiago de Chile: United Nations. 
Engen, E., \& Skinner, J. (1996). Taxation and Economic Growth. National Tax Journal, 49(4), 617-642.

Feldstein, M. (1995). Effect of Marginal Tax Rates on Taxable Income: A Panel Study of the 1986 Tax Reform Act. Journal of Political Economy, 103(3), 551-572.

Frankel, J. A., \& Romer, D. (1999). Does trade cause growth? The American Economic Review, 89(3), 379-399.

Froning, D. H. (2000). The benefits of Free Trade: A guide for policymakers. The Heritage Foundation Backgrounder, 1391.

Gale, W. G., Kearney, M. S., \& Orszag, P. R. (2015). Would a significant increase in the top income tax rate substantially alter income inequality? Economic Studies, Brookings Institution: http://www.brookings.edu/ /media/research/files/papers/2015/09/28-taxes-inequality/would-topincome-tax-alter-income-inequality.pdf.

Gale, W. G., Krupkin, A., \& Rueben, K. (2015). The relationship between taxes and growth at the state level: New wvidence. National Tax Journal, 68(4), 919-941. doi:http://dx.doi.org/10.17310/ntj.2015.4.02

Garfinkle, N. (2005). Supply-side vs. demand-side tax cuts and U.S. economic growth, 1951-2004. Critical Review, 17(3-4), 427-448. doi:10.1080/08913810508443647

Hagen-Zanker, J., \& Tavakoli, H. (2012). An analysis of fiscal space for social protection in Nigeria. London: ODI.

Hardoon, D., Fuentes-Nieva, R., \& Ayele, S. (2016). An Economy For the 1\%: How privilege and power in the economy drive extreme inequality and how this can be stopped. Oxfam Briefing Paper, 210, 1-44: http://oxfamilibrary.openrepository.com/oxfam/bitstream/10546/592643/592647/bp592210-economyone-percent-tax-havens-180116-en.pdf.

Harris, E. (2013). Financing social protection floors: Considerations of fiscal space. International Sociel Security Review, 66(3-4), 111-143.

Heller, P. (2005). Back to Basics. Fiscal Space: What it is and how to get it. Finance and Development, 42(2).

IMF. (2014). Government Fiannce Statistics Manual. Washington, D.C.: International Monetary Fund.

IMF. (2016). Government Finance Statistics database (version 17/02/2016). http://data.imf.org/?sk=a0867067d23c-4ebc-ad23-d3b015045405\&sId=1390030350675.

Kinderman, F., \& Krueger, D. (2014). High Marginal Tax Rates on the Top 1\%? Lessons from a Life Cycle Model with Idiosyncratic Income Risk. NBER Working Paper, 20601: http://www.nber.org/papers/w20601.

Knox-Vydmanov, C. (2011). The price of income security in older age: Cost of a universal pension in 50 low and middle-income countries. Pension watch briefing series, 2, HelpAge International.

Knox-Vydmanov, C., Horn, D., \& Sevilla, A. (2016). The Philippine Social Pension at Four Years: Insights and Recommendations. Manila: Coalition of Services of the Elderly / HelpAge International.

KPMG. (2015). Individual income tax rates table. https://home.kpmg.com/xx/en/home/services/tax/tax-toolsand-resources/tax-rates-online/individual-income-tax-rates-table.html.

Lester, G. L. (2011). Can Joe the Plumber Support Redistribution? Law, Social Preferences, and Sustainable $\begin{array}{llllll}\text { Policy Design. Tax } & \text { Review, } & \text { 64, } & \text { 1-49. }\end{array}$ doi:https://papers.ssrn.com/sol3/papers.cfm?abstract_id=1461098

Letelier S, L. E., \& Dávila A, M. (2015). The Political Economics of Tax Reform in Chile. New Political Economy, 20(6), 832-850. doi:10.1080/13563467.2015.1041475

Lewis, M. (2013). Sweet nothings. The human cost of a British sugar giant avoiding taxes in southern Africa: Action Aid: http://www.actionaid.org.uk/sites/default/files/doc lib/sweet nothings.pdf.

Marcel, M. (2014). Budgeting for fiscal space and government performance beyond the great recession. Paris: OECD Publishing.

Mendizábal, J., \& Escobar, F. (2013). Redistribution of wealth and old age social protection in Bolivia. Pension watch briefing series, 12 , HelpAge International.

Mkandawire, T. (2005). Targeting and Universalism in Poverty Reduction. Social Policy and Development Programme 23, , United Nations Research Institute for Social Development.

Moreira, M. M., \& Najberg, S. (2000). Trade liberalisation in Brazil: Creating or exporting jobs? The Journal of Development Studies, 36(3), 78-99.

Neighbour, J. (2008). Transfer pricing: Keeping it at arm's lenght: OECD Centre for Tax Policy and Administration:

http://www.oecdobserver.org/news/archivestory.php/aid/670/Transfer_pricing:_Keeping_it_at_arms_le ngth.html.

Nirei, M., \& Aoki, S. (2016). Pareto distribution of income in neoclassical growth models. Review of Economic Dynamics, 20, 25-42. doi:http://dx.doi.org/10.1016/j.red.2015.11.002

OECD. (2014). The OECD Economic Outlook: Sources and Methods. https://stats.oecd.org/glossary/detail.asp?ID=628.

Olivier, M. (2013). Social protection in Lesotho: Innovations and reform challenges. Development Southern Africa, 30(1), 98-110. doi:10.1080/0376835X.2012.756218 
Ortiz, I., Cummins, M., \& Karunanethy, K. (2015). Fiscal Space for Social Protection. Options to Expand Social Investments in 187 Countries. Extension of Social Security Working Paper, 48, ILO.

Picciotto, S. (2012). Towards unitary taxation of transnational corporations. Tax Justice Network: http://www.taxjustice.net/wp-content/uploads/2013/04/Towards-Unitary-Taxation-Picciotto-2012.pdf.

Picciotto, S. (2015). Research programme: Unitary Taxation of Transnational Corporations with Special Reference to Developing Countries: International Centre for $\mathrm{Tax}$ and Development: http://www.ictd.ac/unitary-taxation-of-transnational-corporations-with-special-reference-todeveloping-countries.

Piketty, T., Saez, E., \& Stantcheva, S. (2011a). Optimal taxation of Top Labor Incomes: A Tale of Three Elasticities. CEPR Discussion Paper, 8675(December).

Piketty, T., Saez, E., \& Stantcheva, S. (2011b). Taxing the 1\%: Why the top tax rate could be over $80 \%$. CEPR's Policy Portal, http://www.voxeu.org/article/taxing-1-why-top-tax-rate-could-be-over-80\#fn1.

Statistical Bureau of Taiwan. (2016). National Statistics. Republic of China (Taiwan). http://eng.stat.gov.tw/ct.asp?xItem=37408\&CtNode=5347\&mp=5 ,22/03/2016.

UNPD. (2015). World Population Prospects: The 2015 Revision. http://esa.un.org/unpd/wpp/Download/Standard/Population/.

Wex. (2016). Legal Information Institute. Cornell Law School: https://www.law.cornell.edu/wex.

Willmore, L. (2007). Universal pensions for developing countries. World Development, 35(1), $24-51$.

WTO. (2016). World Tariff $\quad$ Profiles. https://www.wto.org/english/tratop_e/tariffs_e/tariff_data_e.htm. 
Figure 1: Disaggregating tax revenue by category in regional and income groups

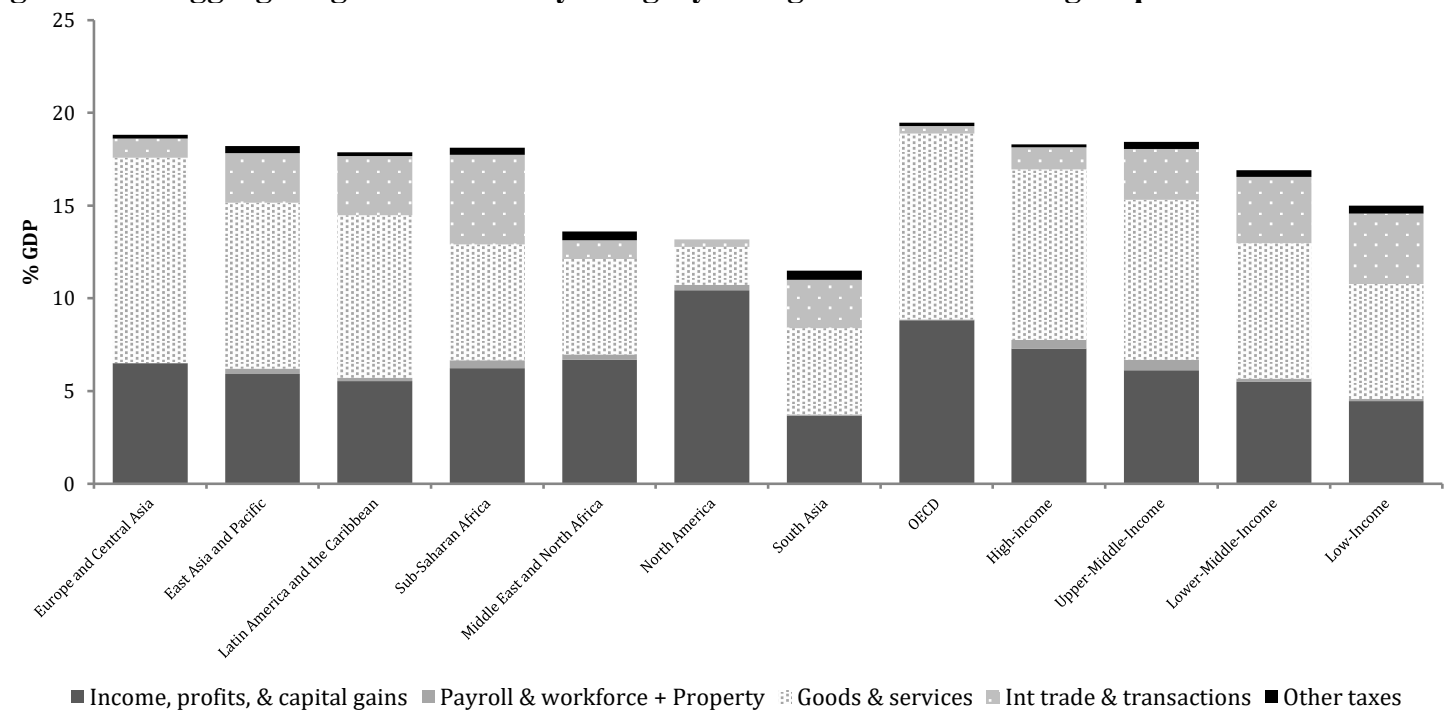

Notes: Data on budgetary central government. The 'payroll and workforce' category was merged with the 'property' category as both represented a minimal part of the tax revenue of most regional and income groups, making it difficult for the reader to identify them in the figure.

Author's calculations; Source: (IMF, 2016)

Figure 2: Potential fiscal space that could be created if the respective countries increased their tax revenues to the OECD mean

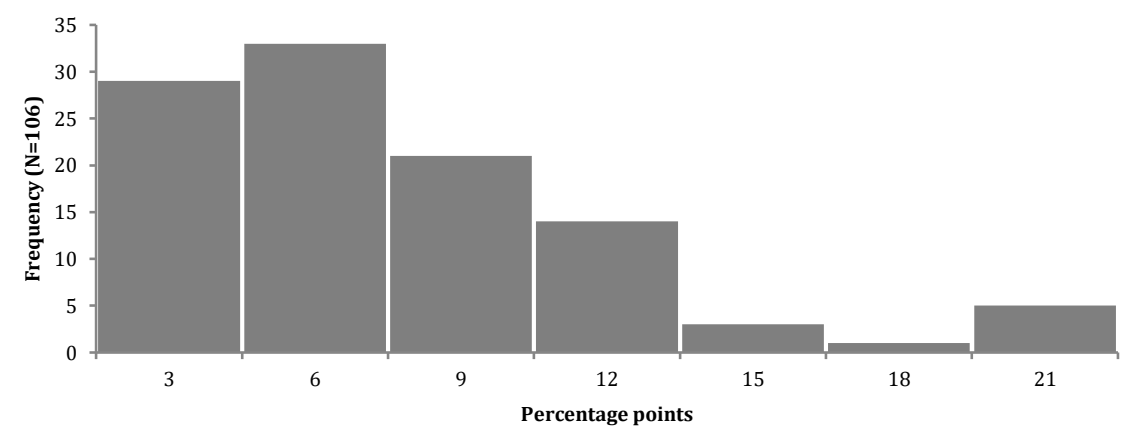

Note: Histogram makes reference to the number of countries ( $y$ axis) that could create a potential fiscal space (in percentage points; $x$ axis) if the cases would increase their tax revenues to the OECD mean.

Author's calculations; Source: (IMF, 2016)

Figure 3: Potential fiscal space that could be created if the respective countries increased their tax revenues to the OECD median

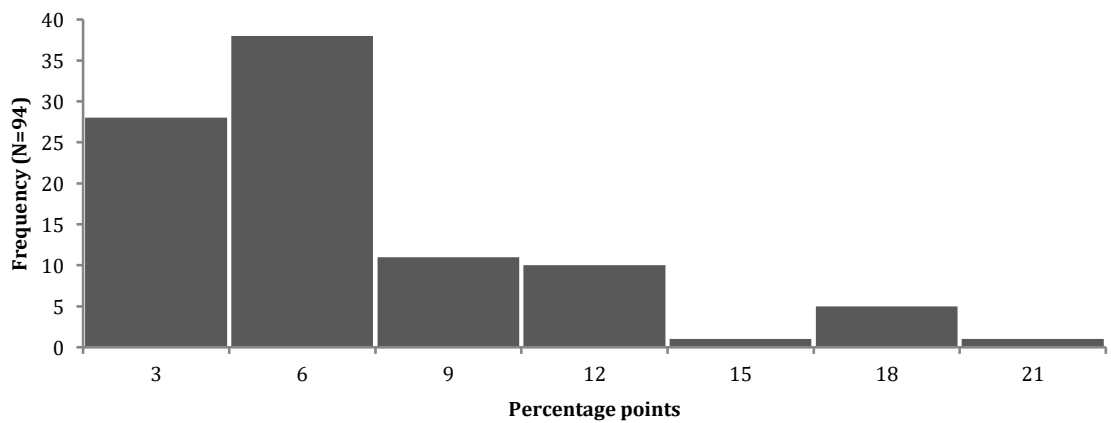

Note: Histogram makes reference to the number of countries (y axis) that could create a potential fiscal space (in percentage points; $\mathrm{x}$ axis) if the cases would increase their tax revenues to the OECD median.

Author's calculations; Source: (IMF, 2016) 
Figure 4: Tax revenue gap of high-, upper-middle, lower-middle, and low-income countries using incomegroup median and OECD median as a threshold
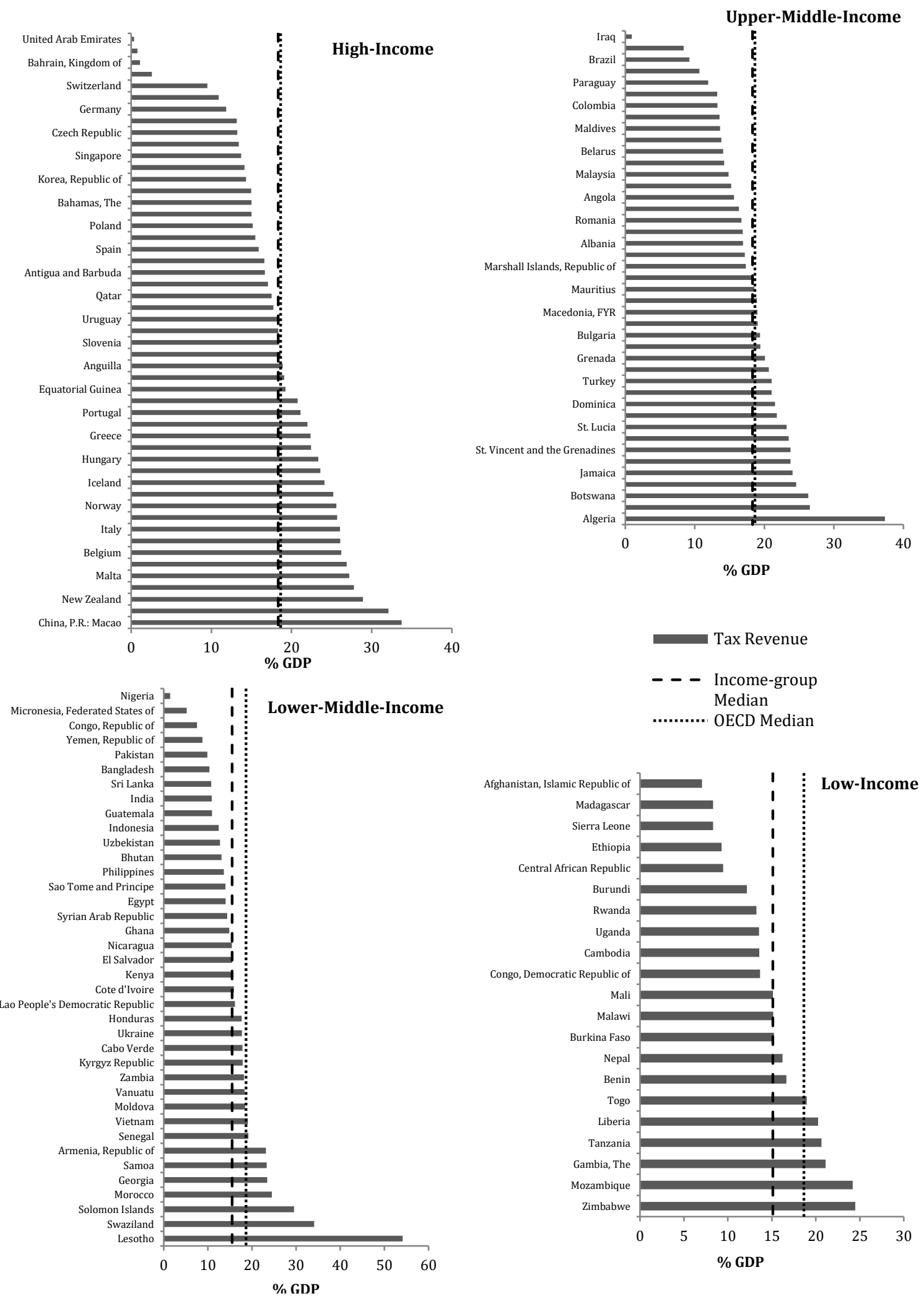

Author's calculations; Source: (IMF, 2016) 
Figure 5: Share of workers employed in the informal economy

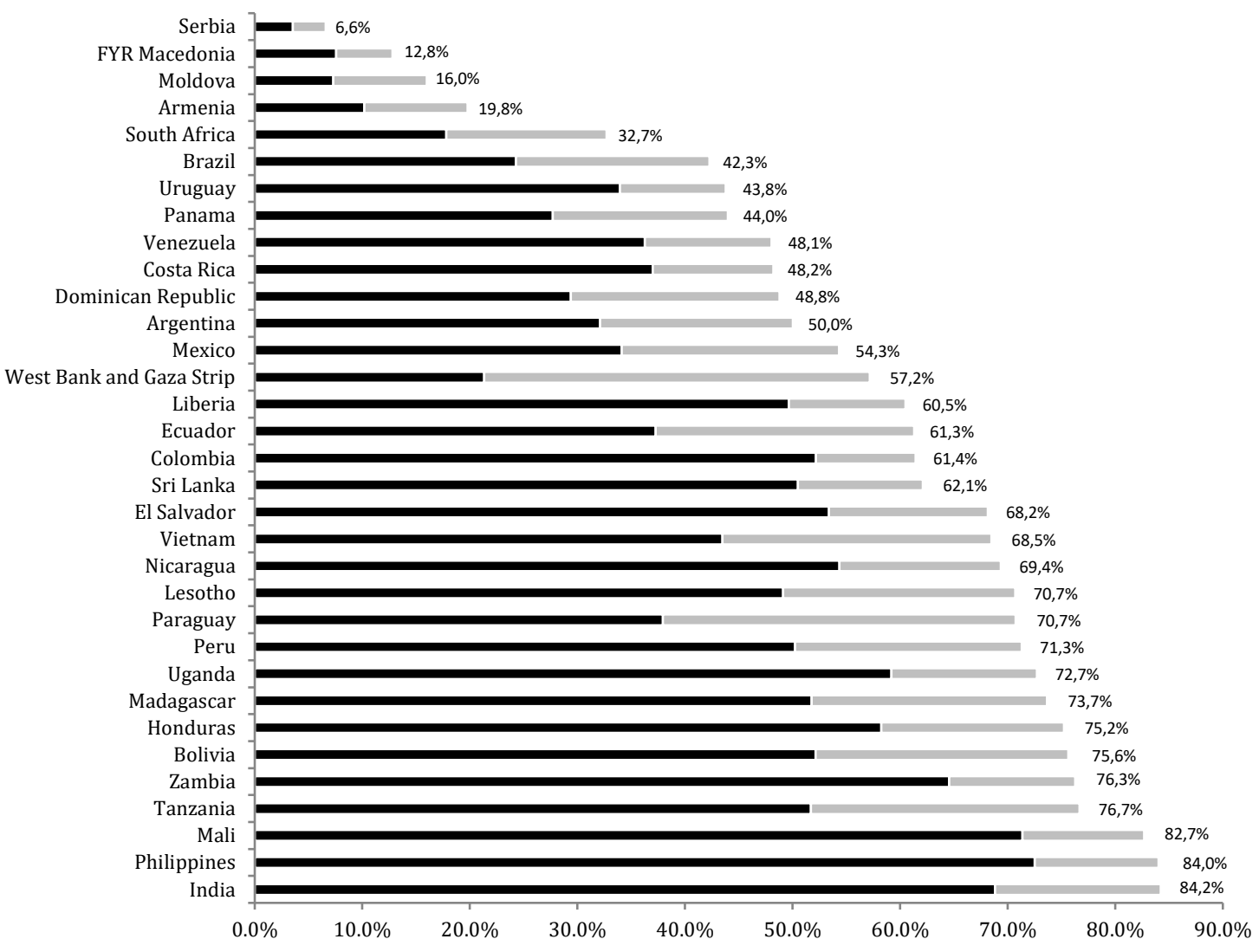

- Share of persons employed in the informal sector $\quad$ Share of persons in informal employment outside the informal sector

\begin{abstract}
Notes: The data refer to non-agricultural employment. According to ILO employment in the informal sector, includes formal employment (if any) in the informal sector, i.e. employee holding formal jobs in informal enterprises. Informal employment outside the informal sector, is for example: employees holding informal jobs in formal enterprises (incl. government units and non-profit-institutions), as paid domestic workers employed by households, or as contributing family workers in formal enterprises. Persons with more than one job during the survey reference period were classified as being employed in the informal sector or in an informal job on the basis of the characteristics of their main job.

*The numbers at the end of the bar refer to the share of persons employed in the informal economy [persons employed in the informal sector (red bar) plus persons in informal employment outside the informal sector (orange bar)].

Author's calculations; Source: (ILO, 2012)
\end{abstract}

Figure 6: Potential fiscal space created by increasing the average tax rate to the top 1 per cent and 5 per cent

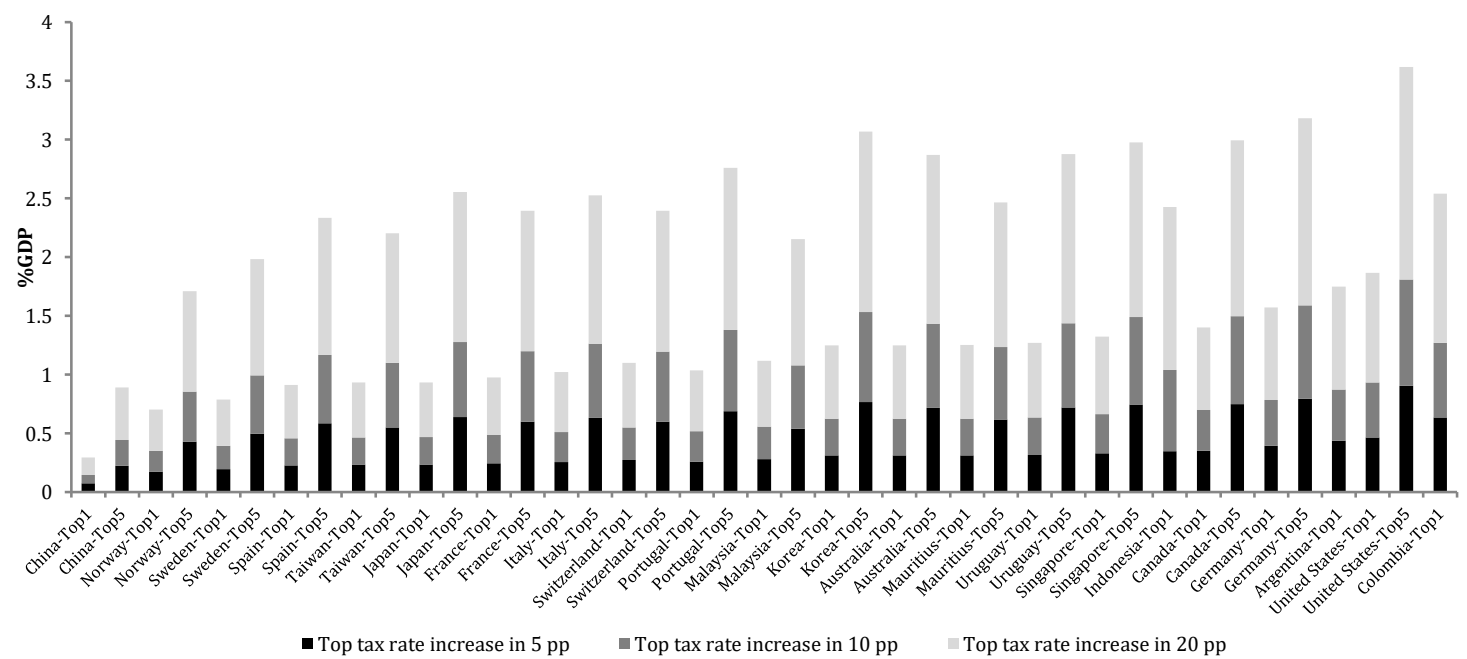

Notes: The graph shows the potential fiscal space created by increasing the average tax rate of the top 1 per cent and 5 per cent income share by 5 (first level), 10 (second level) and 20 (third level) percentage points. Data on the total market income (pre-tax) and the income share of the top 1 per cent and 5 per cent comes from the World Top Incomes Database. All countries with available data are included. There is no available data on the top 5 per cent income share for the cases of Argentina and Colombia. GDP data comes from the World Bank, with the exception of Taiwan which comes from the Statistical Bureau of Taiwan.

Author's calculations; Sources: (Alvaredo et al., 2016; CEDLAS \& Bank, 2016; Statistical Bureau of Taiwan, 2016) 
Figure 7: Fiscal space created by increasing tariffs a 10 per cent

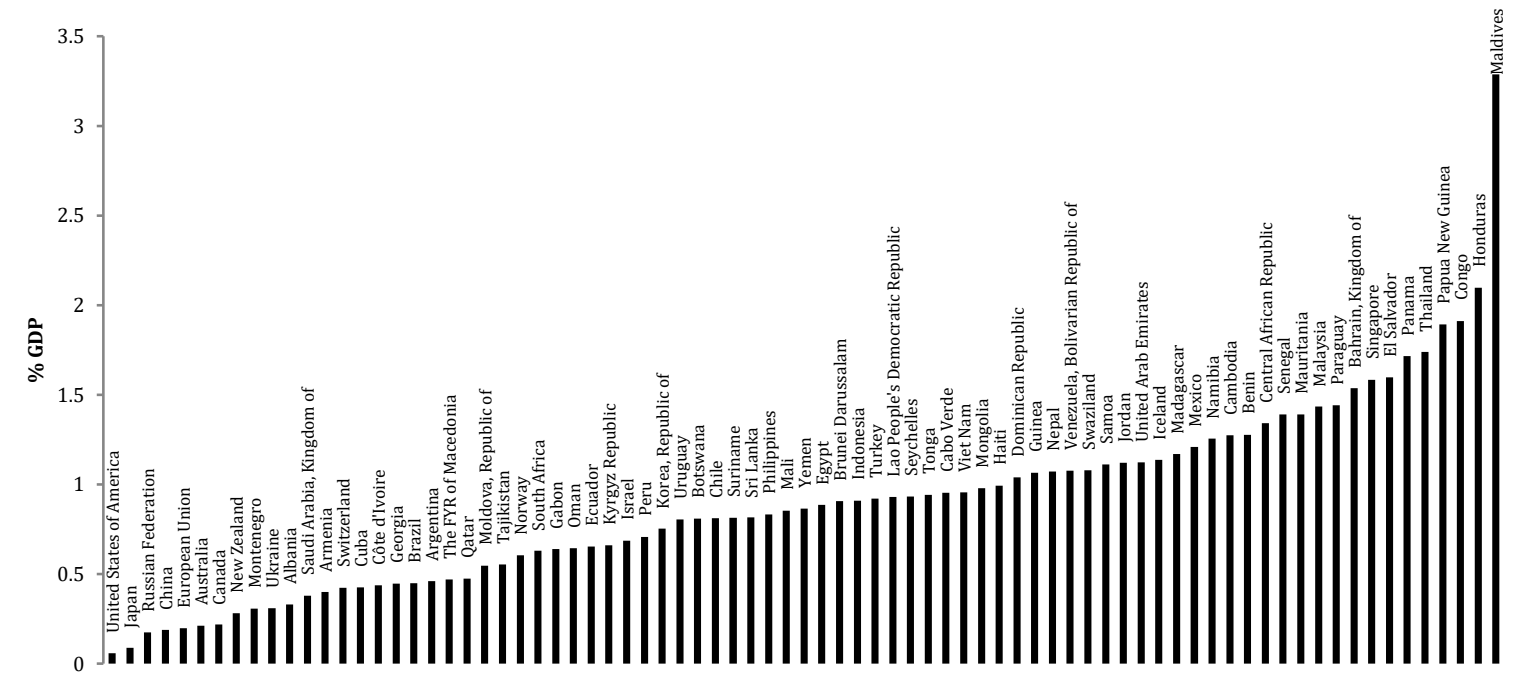

Notes: The product of a 10 per cent raised simple average applied MFN tariff on goods and the value of all imports of goods and services was used to estimate the created fiscal space. The sample is composed of 83 countries with a MFN tariff below the 132 countries sample mean. Hong Kong and Macao does not appear on the graph because their zero per cent actual tariff. Source: (CEDLAS \& Bank, 2016; WTO, 2016) 
Figure 8: Financing social pensions by creating fiscal space through tax revenues
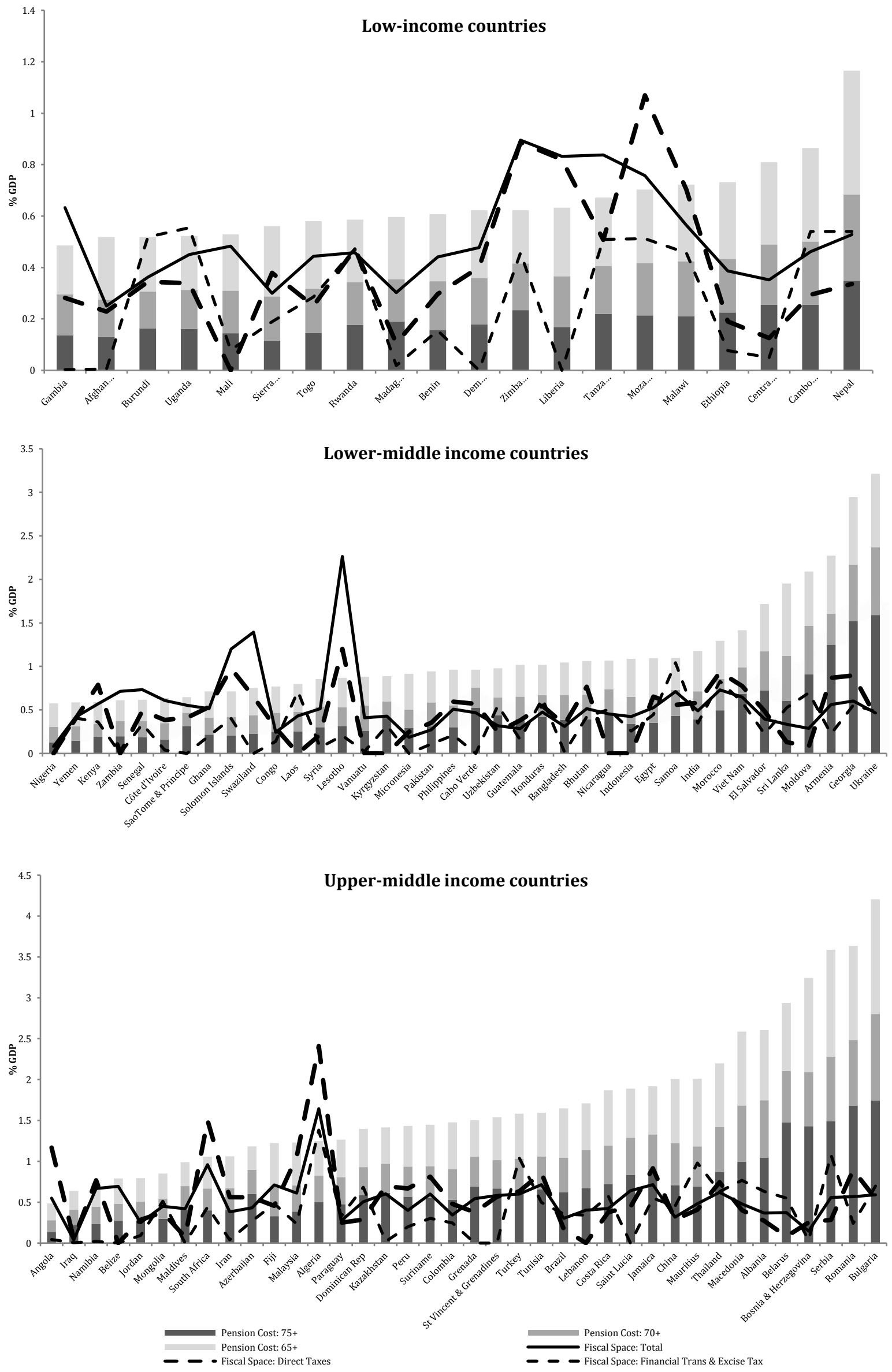